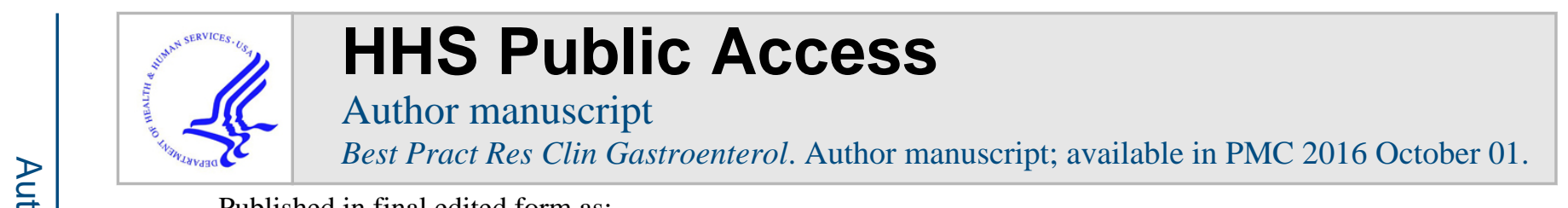

Published in final edited form as:

Best Pract Res Clin Gastroenterol. 2015 October ; 29(5): 721-729. doi:10.1016/j.bpg.2015.06.008.

\title{
Environmental and infectious factors in eosinophilic esophagitis
}

\author{
Elizabeth T. Jensen, MPH, PhD ${ }^{1,2}$ and Evan S. Dellon, MD MPH ${ }^{1,3,{ }^{*}}$ \\ Elizabeth T. Jensen: elizabeth_jensen@med.unc.edu \\ ${ }^{1}$ Center for Esophageal Diseases and Swallowing, Department of Medicine, University of North \\ Carolina School of Medicine, Chapel Hill, NC \\ ${ }^{2}$ Center for Gastrointestinal Biology and Disease, Division of Gastroenterology and Hepatology, \\ Department of Medicine, University of North Carolina School of Medicine, Chapel Hill, NC \\ ${ }^{3}$ Department of Epidemiology, Gillings School of Global Public Health, University of North \\ Carolina, Chapel Hill, NC
}

\section{Abstract}

Identifying possible environmental or infectious etiologic factors for eosinophilic esophagitis (EoE) may offer insight into opportunities for disease prevention and treatment. We reviewed the current literature to assess environmental and infectious factors evaluated in EoE. Few studies have been conducted, however a consistent inverse association between EoE and $H$. pylori has been described. Several studies suggest a weak association between season and EoE diagnosis, but the evidence is inconclusive. EoE has also been associated with early life factors, including Cesarean delivery and antibiotic use. Larger studies are needed to evaluate these associations more thoroughly. Several papers have speculated the potential for anti-secretory agents to contribute to EoE. This has not been formerly evaluated. In summary, there is significant opportunity in the future to advance our understanding of possible environmental etiologic factors for EoE.

\section{Keywords}

eosinophilic esophagitis; etiology; environment; infection; epidemiology; risk factors

\section{Introduction}

Much of the literature on eosinophilic esophagitis (EoE) focuses on either clinical aspects of the disease, i.e. diagnosis, treatment, and natural history, or the underlying molecular

\footnotetext{
*corresponding author: Evan S. Dellon MD, MPH, CB\#7080, Bioinformatics Building, 130 Mason Farm Rd., UNC-CH, Chapel Hill, NC 27599-7080, Phone: (919) 966-2513, Fax: (919) 843-2508, edellon@med.unc.edu.

Author contact information:

Elizabeth T. Jensen MPH, PhD, CB\#7080, Bioinformatics Building, 130 Mason Farm Rd., UNC-CH, Chapel Hill, NC 27599-7080, Phone: (919) 316-4797, Fax: (919) 843-2508

Publisher's Disclaimer: This is a PDF file of an unedited manuscript that has been accepted for publication. As a service to our customers we are providing this early version of the manuscript. The manuscript will undergo copyediting, typesetting, and review of the resulting proof before it is published in its final citable form. Please note that during the production process errors may be discovered which could affect the content, and all legal disclaimers that apply to the journal pertain.

Conflict of interest

No relevant conflicts
} 
pathways for disease development and progression. Additionally, several studies have examined the descriptive epidemiology of EoE (i.e. estimating disease incidence, prevalence and demographic features of affected patients).(1-12) Although these studies have greatly enhanced our understanding of this increasingly common disease, $(13,14)$ our understanding of etiologic risk factors for disease remains elusive. Studies of genetics have identified several susceptibility loci for disease development,(15-18) and these are described elsewhere in this issue, but recent family studies suggest that relatively little of the disease can be explained by heritability alone.(19) This, together with the rapidly increasing incidence of disease that is not entirely explained by increased diagnostic awareness or volume of upper endoscopy procedures, $(9,12,20)$ suggests that environmental factors not only contribute, but likely play a large role in EoE etiology. Understanding which environmental factors contribute to disease development is not simply an academic exercise. Identifying etiologic risk factors for disease offers the opportunity to improve our understanding of disease pathogenesis, thus helping us to identify opportunities for prevention, as well as treatment targets that may interrupt disease course.

In this review, we discuss the literature published to date on environmental and infectious etiologic factors in development of EoE. We focus on the several areas of research that have been explored thus far, including seasonal and geographical differences, possible infectious origins of disease, perinatal and early childhood factors that may contribute, and pharmacologic risk factors, specifically use of anti-secretory agents. In each of these areas of research we discuss the existing evidence in support of these factors contributing to disease development and, where applicable, identify opportunities for future research. While food triggers, may be considered an environmental cause of EoE, a detailed review of the role of allergy and food antigens is beyond the scope of this paper, and this topic is addressed elsewhere in this issue.

\section{Seasonal differences}

The question of possible seasonal differences in diagnosis of EoE has been evaluated in several studies. Identifying seasonal differences in the distribution of disease diagnosis would provide support to the literature suggesting that aeroallergens are associated with disease pathogenesis,(21-24) and the subject of aeroallergens is explored in detail elsewhere in this issue. Generally, most of the studies conducted on season and EoE are suggestive of a modest association, typically with an increase in diagnosis in the Summer or Fall months. (12, 25-32) Most of these studies, however, have been conducted at single center sites and were unable to account for possible climate differences (Table 1).

Although seasonal differences in aeroallergens are the most obvious explanation for any association between season and EoE, there are other factors that vary by season, including differences in dietary patterns due to availability of fresh produce and differences in air quality in different seasons. Diet related triggers for EoE have been explored extensively, as these form the basis for food-related therapeutic approaches to treatment for EoE. Air quality factors have not been directly studied in EoE, but have been associated with development of other atopic diseases.(33-35)

Best Pract Res Clin Gastroenterol. Author manuscript; available in PMC 2016 October 01. 


\section{Geographic differences}

A difference in the geographical distribution of disease has been documented for other gastrointestinal diseases although only a few studies have evaluated this in EoE. Any differences observed could provide clues into possible environmental contributors to disease etiology. A single-center, case control study ( $\mathrm{n}=508$ cases, $\mathrm{n}=508$ GI controls, and $\mathrm{n}=508$ allergy controls) conducted in the Greater Philadelphia area observed that patients diagnosed with EoE were more likely to reside in suburban areas when compared to allergy clinic identified controls (adjusted OR: 2.08; 95\% CI: 1.22, 3.54).(36) However, no association was found when comparing EoE patients to GI clinic obtained controls (adjusted OR: 0.82; 95\% CI: 0.46, 1.45).(36) A case-control study ( $\mathrm{n}=14,381$ cases and $\mathrm{n}=89,754$ controls), using a large pathology database with cases from throughout the U.S. identified an association between EoE and population density, with increasingly rural areas exhibiting increasingly higher odds of diagnosis (adjusted OR: 1.41; 95\% CI: 1.14, 1.76 for the least populous zip code residences).(37) The association was robust to using a variety of case definitions with increased specificity for EoE. While increased odds of EoE in rural areas is somewhat counter to what has been found in other allergic diseases, a similar finding was noted in a survey study of gastroenterologists and allergists.(38) Another study, from the large national pathology database noted above, observed that the prevalence of EoE varied by climate zone, with cold climate zones exhibiting the greatest odds of disease as compared to temperate climates (adjusted OR: 1.39; 95\% CI: 1.34, 1.47).(39)

The implications of this variation in geographical distribution are that there may be environmental factors associated with population density or climate that are contributing to disease etiology, although direct study of these factors is needed. For lower population density areas, there may be agricultural exposures, different foliage patterns, or differences in particulate matter size or species that contribute. These hypotheses are speculative, but these studies provide support for additional investigation.

\section{Infectious origins}

\section{Helicobacter pylori}

While most studies examining risk factors for EoE have looked for environmental factors that are increasing in association with the increase in EoE, it is also possible to look for something that has been decreasing in the environment. Helicobacter pylori is one such potential factor. Since it's identification as a major cause of peptic ulcer disease and gastric cancer, H. pylori has been eradicated when found, leading to decreasing rates of colonization and infection throughout the U.S. $(40,41)$ Additionally, this decrease in $H$. pylori has been associated with the increase of other atopic conditions, including asthma, allergic rhinitis, and atopic dermatitis.(42-45)

Recently, a series of studies has demonstrated that $H$. pylori is also inversely associated with EoE. This observation appears to hold in both adult and pediatric populations and in multiple settings (Table 2).(46-50) For example, in the largest of these studies ( $\mathrm{n}=5,767$ cases, $\mathrm{n}=56,301$ controls) which used a national pathology database from biopsies obtained in 41 states throughout the U.S., the odds of EoE among patients with conformed H. pylori 
infection was 0.79 (95\% CI: 0.70, 0.88). While the underlying reason for this inverse association is not known, and causality has yet to be determined in an experimental model, it is possible that lack of $H$. pylori either has a direct effect (Th2 vs Th2 polarization), or that it is a marker for the hygiene hypothesis.(46) The underlying premise for this hypothesis is that the lack of exposure to childhood infections and improved sanitation has caused a lack of immune tolerance. $(42,51,52)$ However, whether this applies to EoE has yet to be examined directly. Alternatively, H. pylori has also been inversely associated with gastroesophageal reflux disease (53). Given the association between EoE and reflux, it may be that the decrease in $H$. pylori is driven by the inverse association shared between GERD and $H$. pylori. This hypothesis also requires additional future investigation.

\section{Herpes Simplex Virus and other potential infectious etiologies}

Case reports of herpes simplex virus (HSV) esophagitis and subsequent development of EoE suggest that there may be a potential link between these two conditions. In a case series from Melbourne, Australia, three children (ages 9-16) presented with herpetic esophagitis.(54) While none had evidence of EoE at the time HSV positive biopsies were obtained from the esophagus, all three developed esophageal eosinophil infiltration consistent with EoE (all had > 30 eos/hpf) within the following 1-2 months. All three patients had history of atopy, suggesting there may have been an underlying predisposition toward EoE. In a similar case report, a 17 year old adolescent with concomitant atopy presented with signs of both herpes esophagitis and EoE at the initial endoscopy.(55) Subsequent biopsy showed increased eosinophils (34 eos/hpf) and the presence of HSV I. Follow-up at 2 and 3 months indicated resolution of HSV but persistent EoE. Despite these isolated cases, as well as ones that report HSV as complicating topical steroid therapy in EoE,(56) additional research is needed to assess the extent to which these conditions co-exist, the temporality in the association between the conditions, and whether herpes simplex esophagitis is a causal agent in susceptible individuals. $(57,58)$

Other infections that have been examined in relation to EoE are mycoplasma pneumonia and IgE sensitization from tick-borne, galactose-alpha-1,3-galactose (alpha gal). For $m$. pneumonia, 10 of 12 children were IgG positive with serologic testing for $m$. pneumonia. (59) However, further study is needed to establish the seroprevalence of IgG for $m$. pneumonia in controls before any association with EoE can be inferred.

In a case-control study ( $n=50$ cases, $n=50$ controls), sera biobanked from adult EoE cases and controls undergoing upper endoscopy were evaluated for IgE sensitization for alpha gal. This study found a high rate of sensitization in both cases and controls being seen for upper endoscopy, but no difference between cases and controls in the absolute IgE count or proportion with sensitization (defined as $>0.35 \mathrm{kU}_{\mathrm{A}} / \mathrm{L}$ ).(60) Therefore, it does not appear that the recent discovery of a tick-induced food allergy is a risk factor for EoE.

\section{Early life factors}

To date, few studies have explored early life factors associated with the development of EoE, but based on parallels with other atopic conditions, understanding this critical time period is an important future direction for EoE research. For example, allergic and other 
immune-mediated diseases have been hypothesized to be associated with changes in gut microbiota in early life potentially resulting from changes in diet, antibiotic exposure, Cesarean deliveries, infant feeding practices and breast milk exposure, and reduced exposure to microbial disease (the hygiene hypothesis).(46, 61-65) Preliminary data suggest that similar risk factors could be important in EoE. In a case-control study of 31 children with EoE, there was an association between certain early life factors and development of EoE in children.(66) These factors included cesarean delivery, preterm delivery, and antibiotic use in infancy, although only antibiotic use in the first year of life reached statistical significance (OR 6.1, 95\% CI: 1.7, 20.8). Another small case control study (25 EoE cases) recently reported similar results, with both cesarean delivery and antibiotic use in the first year of life associated with EoE (OR 3.2 (95\% CI 1.2, 8.6) and 3.6 (95\% CI 1.3, 10.1) respectively).(67) These studies, although suggestive of the potential for early life factors contributing to disease pathogenesis, were based on data collected from questionnaires and may be subject to recall bias, or, for antibiotic use, subject to confounding by indication. Moreover, there are no studies in EoE that show that an alteration of the microbiome is directly responsive for disease onset. Therefore, additional larger and mechanistic studies are warranted to explore these associations further.

\section{Anti-secretory agents}

Because proton pump inhibitors (PPIs) are one of the most commonly used medications (68), were introduced more than 30 years ago around the time of the first cases reports of EoE,(69) and have had markedly increasing use infants in recent years, $(70,71)$ it is intriguing to speculate whether there is an association between PPIs and EoE. In 2009, Merwat and Spechler commented on the potential for anti-secretory agents to cause EoE. (72) They posited that $\mathrm{H} 2$ receptor antagonists and PPIs alter the permeability of the mucosa in the upper gastrointestinal tract and could allow increased uptake of allergens, subsequently leading to recruitment of eosinophils. While this has never been shown in EoE, this hypothesis is informed by studies showing that patients with reflux esophagitis and Barrett's esophagus taking anti-secretory agents have increased mucosal permeability to sucrose,(73) similar to the increased mucosal permeability seen in animal models following use of an anti-secretory agent.(74) Increased gut permeability, in genetically susceptible individuals, may compromise oral tolerance and lead to development of food allergies. In animal models and human studies, antacid medications have inhibited digestion of dietary proteins and resulted in development of $\operatorname{IgE}$ antibodies in response to the dietary protein. (75-77). PPIs have also been associated with hypersensitivity reactions to medications in hospitalized patients.(78) Observational studies have suggested that use of an anti-secretory agent in pregnancy can increase risk of atopic illness in the offspring,(79-81) but the mechanism is unknown. One possibility that has been raised is that maternal use of these agents could interfere with normal digestion of dietary proteins, possibly resulting in preservation of antigens that could be transferred to and induce a Th2 response in the fetus. (82-84)

Because the possible association between anti-secretory agents and EoE has not been formally assessed, this theory remains controversial and there is an active debate in the literature. For example, in one report, there was no evidence of either an absolute increase in 
EoE or a dose-response among PPI users after 400 patients undergoing outpatient upper endoscopy were assessed.(85) In contrast, three cases of EoE have been reported following PPI use after an initial diagnosis of either reflux esophagitis or infectious esophagitis.(25, 86) Finally, at least one study has suggested that PPIs can decrease the permeability of the esophageal mucosa in GERD patients.(87) As with many of the potential risk factors of EoE, additional work is needed to clarify the importance of these associations.

\section{Research agenda}

- Environmental changes are likely key in the development of EoE, but few studies have been conducted on possible non-food environmental factors that may contribute to the pathogenesis of EoE.

- Recent data have suggested that EoE is associated with seasonality, climate zone, and geographic factors such as population density. However, additional work is needed to determine the specific triggers associated with these factors.

- An inverse association between H. pylori and EoE has been demonstrated in a number of studies. Whether this relation is causal, and what mechanisms might underlie this, however, have yet to be investigated.

- Early life factors may contribute to disease development, potentially through immune dysregulation. Two small studies suggest are suggestive of an association with cesarean delivery and antibiotic use in early life, however larger studies are needed.

- Speculation that anti-secretory agents may be associated with EoE is intriguing but controversial, and warrants further investigation. However, confounding by indication and recall bias, as well as the availability of these medications over the counter, will be issues in such studies.

\section{Summary}

Identifying etiologic risk factors for EoE offers the opportunity to improve our understanding of disease pathogenesis, thus helping us to identify opportunities for prevention, as well as treatment strategies that may interrupt disease course. Heritability explains relatively little of disease development and thus, environmental factors are important. However, few studies have been conducted on possible environmental factors that may contribute to the pathogenesis of EoE. The studies conducted to date suggest that geography (rural location; cold or arid climate zones), absence of $H$. pylori infection, and early life factors (antibiotic use during infancy; Cesarean delivery), which might alter gut microbiota, are associated with disease development. With few exceptions, most studies conducted have been relatively small, and have not been confirmed by mechanistic investigations. Therefore, the association between environment and EoE is an underdeveloped but important area of research in the field.

\section{Acknowledgments}

None 


\section{Role of the funding source}

This work was supported, in part, by NIH Awards K23 DK090073 (ESD) and U54AI117804 (CEGIR), which is part of the Rare Disease Clinical Research Network (RDCRN), an initiative of the Office of Rare Disease Research (ORDR), NCATS, and is funded through collaboration between NIAID, NIDDK, and NCATS.

\section{References}

1. Cherian S, Smith NM, Forbes DA. Rapidly increasing prevalence of eosinophilic oesophagitis in Western Australia. Arch Dis Child. 2006; 91:1000-4. [PubMed: 16877474]

2. Dalby K, Nielsen RG, Kruse-Andersen S, Fenger C, Bindslev-Jensen C, Ljungberg S, et al. Eosinophilic Oesophagitis in Infants and Children in the Region of Southern Denmark: A Prospective Study of Prevalence and Clinical Presentation. J Pediatr Gastroenterol Nutr. 2010; 51:280-2. [PubMed: 20512060]

3. Dellon ES, Jensen ET, Martin CF, Shaheen NJ, Kappelman MD. Prevalence of eosinophilic esophagitis in the United States. Clinical gastroenterology and hepatology : the official clinical practice journal of the American Gastroenterological Association. 2014; 12(4):589-96e1. [PubMed: 24035773]

4. Garcia-Compean D, Gonzalez Gonzalez JA, Marrufo Garcia CA, Flores Gutierrez JP, Barboza Quintana O, Galindo Rodriguez G, et al. Prevalence of eosinophilic esophagitis in patients with refractory gastroesophageal reflux disease symptoms: A prospective study. Dig Liver Dis. 2011; 43(3):204-8. [PubMed: 20843755]

5. Gill R, Durst P, Rewalt M, Elitsur Y. Eosinophilic Esophagitis Disease in Children from West Virginia: A Review of the Last Decade (1995-2004). Am J Gastroenterol. 2007; 102:2281-5. [PubMed: 17573789]

6. Kapel RC, Miller JK, Torres C, Aksoy S, Lash R, Katzka DA. Eosinophilic esophagitis: a prevalent disease in the United States that affects all age groups. Gastroenterology. 2008; 134(5):1316-21. [PubMed: 18471509]

7. Nielsen RG, Husby S. Eosinophilic oesophagitis: epidemiology, clinical aspects, and association to allergy. J Pediatr Gastroenterol Nutr. 2007; 45(3):281-9. [PubMed: 17873738]

8. Prasad GA, Alexander JA, Arora AS, Talley Nj, Romero Y, Glenn AL, et al. Eosinophilic esophagitis: Prevalence and predictive factors. Am J Gastroenterol. 2006; 101(9 Suppl):S60-1. (A56).

9. Prasad GA, Alexander JA, Schleck CD, Zinsmeister AR, Smyrk TC, Elias RM, et al. Epidemiology of eosinophilic esophagitis over three decades in Olmsted County, Minnesota. Clin Gastroenterol Hepatol. 2009; 7(10):1055-61. [PubMed: 19577011]

10. Straumann A, Spichtin HP, Grize L, Bucher KA, Beglinger C, Simon HU. Natural history of primary eosinophilic esophagitis: a follow-up of 30 adult patients for up to 11.5 years. Gastroenterology. 2003; 125(6):1660-9. [PubMed: 14724818]

11. Spergel JM, Brown-Whitehorn TF, Beausoleil JL, Franciosi J, Shuker M, Verma R, et al. 14 Years of Eosinophilic Esophagitis: Clinical Features and Prognosis. J Pediatr Gastroenterol Nutr. 2009; 48(1):30-6. [PubMed: 19172120]

12. Dellon ES, Gibbs WB, Fritchie KJ, Rubinas TC, Wilson LA, Woosley JT, et al. Clinical, endoscopic, and histologic findings distinguish eosinophilic esophagitis from gastroesophageal reflux disease. Clinical gastroenterology and hepatology : the official clinical practice journal of the American Gastroenterological Association. 2009; 7(12):1305-13. quiz 261. [PubMed: 19733260]

13. Dellon ES, Liacouras CA. Advances in clinical management of eosinophilic esophagitis. Gastroenterology. 2014; 147(6):1238-54. [PubMed: 25109885]

14. Rothenberg ME. Molecular, Genetic, and Cellular Bases for Treating Eosinophilic Esophagitis. Gastroenterology. 2015

15. Blanchard C, Wang N, Rothenberg ME. Eosinophilic esophagitis: pathogenesis, genetics, and therapy. J Allergy Clin Immunol. 2006; 118(5):1054-9. [PubMed: 17088129] 
16. Blanchard C, Wang N, Stringer KF, Mishra A, Fulkerson PC, Abonia JP, et al. Eotaxin-3 and a uniquely conserved gene-expression profile in eosinophilic esophagitis. J Clin Invest. 2006; 116(2):536-47. [PubMed: 16453027]

17. Kottyan LC, Davis BP, Sherrill JD, Liu K, Rochman M, Kaufman K, et al. Genome-wide association analysis of eosinophilic esophagitis provides insight into the tissue specificity of this allergic disease. Nature genetics. 2014; 46(8):895-900. [PubMed: 25017104]

18. Sherrill JD, Blanchard C. Genetics of eosinophilic esophagitis. Dig Dis. 2014; 32(1-2):22-9. [PubMed: 24603376]

19. Alexander ES, Martin LJ, Collins MH, Kottyan LC, Sucharew H, He H, et al. Twin and family studies reveal strong environmental and weaker genetic cues explaining heritability of eosinophilic esophagitis. J Allergy Clin Immunol. 2014; 134(5):1084-92 e1. [PubMed: 25258143]

20. Dellon ES, Erichsen R, Baron JA, Shaheen NJ, Vyberg M, Sorensen HT, et al. The increasing incidence and prevalence of eosinophilic oesophagitis outpaces changes in endoscopic and biopsy practice: national population-based estimates from Denmark. Alimentary pharmacology \& therapeutics. 2015; 41(7):662-70. [PubMed: 25684441]

21. Chadha SN, Wang L, Correa H, Moulton D, Hummell DS. Pediatric eosinophilic esophagitis: the Vanderbilt experience. Annals of allergy, asthma \& immunology : official publication of the American College of Allergy, Asthma, \& Immunology. 2014; 113(4):445-51.

22. Fogg MI, Ruchelli E, Spergel JM. Pollen and eosinophilic esophagitis. J Allergy Clin Immunol. 2003; 112(4):796-7. [PubMed: 14564365]

23. Moawad FJ, Veerappan GR, Lake JM, Maydonovitch CL, Haymore BR, Kosisky SE, et al. Correlation between eosinophilic oesophagitis and aeroallergens. Alimentary pharmacology \& therapeutics. 2010; 31(4):509-15. [PubMed: 19925501]

24. Wolf WA, Jerath MR, Dellon ES. De-novo onset of eosinophilic esophagitis after large volume allergen exposures. J Gastrointestin Liver Dis. 2013; 22(2):205-8. [PubMed: 23799220]

25. Sorser SA, Barawi M, Hagglund K, Almojaned M, Lyons H. Eosinophilic esophagitis in children and adolescents: epidemiology, clinical presentation and seasonal variation. J Gastroenterol. 2013; 48(1):81-5. [PubMed: 22618806]

26. Frederickson NW, Bayman L, Valestin J, Redd M, Lee YJ, Soubra M, et al. Lack of seasonal variation in the incidence of eosinophilic oesophagitis in adolescent and adult non-PPI-responsive oesophageal eosinophilia midwestern US populations. United Eur Gastroent. 2014; 2(2):69-76.

27. Elias M, Kopacova J, Arora A, Dierkhising R, Enders F, Katzka D, et al. The Diagnosis of Esophageal Eosinophilia is Not Increased in the Summer Months. Dysphagia. 2015; 30(1):67-73. [PubMed: 25288197]

28. Almansa C, Krishna M, Buchner AM, Ghabril MS, Talley N, DeVault KR, et al. Seasonal distribution in newly diagnosed cases of eosinophilic esophagitis in adults. Am J Gastroenterol. 2009; 104(4):828-33. [PubMed: 19240704]

29. Wang FY, Gupta SK, Fitzgerald JF. Is there a seasonal variation in the incidence or intensity of allergic eosinophilic esophagitis in newly diagnosed children? J Clin Gastroenterol. 2007; 41(5): 451-3. [PubMed: 17450024]

30. Iwanczak B, Janczyk W, Ryzko J, Banaszkiewicz A, Radzikowski A, Jarocka-Cyrta E, et al. Eosinophilic esophagitis in children: frequency, clinical manifestations, endoscopic findings, and seasonal distribution. Adv Med Sci. 2011; 56(2):151-7. [PubMed: 22008313]

31. Elitsur Y, Aswani R, Lund V, Dementieva Y. Seasonal distribution and eosinophilic esophagitis: the experience in children living in rural communities. J Clin Gastroenterol. 2013; 47(3):287-8. [PubMed: 23164688]

32. Larsson H, Bergquist H, Bove M. The incidence of esophageal bolus impaction: is there a seasonal variation? Otolaryngol Head Neck Surg. 2011; 144(2):186-90. [PubMed: 21493413]

33. Morgenstern V, Zutavern A, Cyrys J, Brockow I, Koletzko S, Krämer U, et al. Atopic Diseases, Allergic Sensitization, and Exposure to Traffic-related Air Pollution in Children. American journal of respiratory and critical care medicine. 2008; 177(12):1331-7. [PubMed: 18337595]

34. Salam MT, Li Y-F, Langholz B, Gilliland FD, Children's Health S. Early-life environmental risk factors for asthma: findings from the Children's Health Study. Environmental health perspectives. 2004; 112(6):760-5. [PubMed: 15121522] 
35. Fry RC, Rager JE, Zhou H, Zou B, Brickey JW, Ting J, et al. Individuals with increased inflammatory response to ozone demonstrate muted signaling of immune cell trafficking pathways. Respiratory Research. 2012; 13(1):89-. [PubMed: 23033980]

36. Franciosi JP, Tam V, Liacouras CA, Spergel JM. A case-control study of sociodemographic and geographic characteristics of 335 children with eosinophilic esophagitis. Clin Gastroenterol Hepatol. 2009; 7(4):415-9. [PubMed: 19118642]

37. Jensen ET, Hoffman K, Shaheen NJ, Genta RM, Dellon ES. Esophageal eosinophilia is increased in rural areas with low population density: results from a national pathology database. Am J Gastroenterol. 2014; 109(5):668-75. [PubMed: 24667575]

38. Spergel JM, Book WM, Mays E, Song L, Shah SS, Talley NJ, et al. Variation in prevalence, diagnostic criteria, and initial management options for eosinophilic gastrointestinal diseases in the United States. J Pediatr Gastroenterol Nutr. 2011; 52(3):300-6. [PubMed: 21057327]

39. Hurrell JM, Genta RM, Dellon ES. Prevalence of esophageal eosinophilia varies by climate zone in the United States. Am J Gastroenterol. 2012; 107(5):698-706. [PubMed: 22310220]

40. Everhart JE, Kruszon-Moran D, Perez-Perez GI, Tralka TS, McQuillan G. Seroprevalence and ethnic differences in Helicobacter pylori infection among adults in the United States. The Journal of infectious diseases. 2000; 181(4):1359-63. [PubMed: 10762567]

41. Grad YH, Lipsitch M, Aiello AE. Secular trends in Helicobacter pylori seroprevalence in adults in the United States: evidence for sustained race/ethnic disparities. Am J Epidemiol. 2012; 175(1): 54-9. [PubMed: 22085628]

42. Chen Y, Blaser MJ. Inverse associations of Helicobacter pylori with asthma and allergy. Arch Intern Med. 2007; 167(8):821-7. [PubMed: 17452546]

43. Chen Y, Blaser MJ. Helicobacter pylori colonization is inversely associated with childhood asthma. J Infect Dis. 2008; 198(4):553-60. [PubMed: 18598192]

44. D’Elios MM, Codolo G, Amedei A, Mazzi P, Berton G, Zanotti G, et al. Helicobacter pylori, asthma and allergy. FEMS Immunol Med Microbiol. 2009; 56(1):1-8. [PubMed: 19220467]

45. Reibman J, Marmor M, Filner J, Fernandez-Beros ME, Rogers L, Perez-Perez GI, et al. Asthma is inversely associated with Helicobacter pylori status in an urban population. PLoS One. 2008; 3(12):e4060. [PubMed: 19112508]

46. Dellon ES, Peery AF, Shaheen NJ, Morgan DR, Hurrell JM, Lash RH, et al. Inverse association of esophageal eosinophilia with Helicobacter pylori based on analysis of a US pathology database. Gastroenterology. 2011; 141(5):1586-92. [PubMed: 21762663]

47. Furuta K, Adachi K, Aimi M, Ishimura N, Sato S, Ishihara S, et al. Case-control study of association of eosinophilic gastrointestinal disorders with Helicobacter pylori infection in Japan. Journal of clinical biochemistry and nutrition. 2013; 53(1):60-2. [PubMed: 23874072]

48. Elitsur Y, Alrazzak BA, Preston D, Demetieva Y. Does Helicobacter pylori protect against eosinophilic esophagitis in children? Helicobacter. 2014; 19(5):367-71. [PubMed: 24750254]

49. Ronkainen J, Talley NJ, Aro P, Storskrubb T, Johansson SE, Lind T, et al. Prevalence of oesophageal eosinophils and eosinophilic oesophagitis in adults: The population-based Kalixanda study. Gut. 2007; 56:615-20. [PubMed: 17135307]

50. von Arnim U, Wex T, Miehlke S, Link A, Malfertheiner P. Mo1869 Inverse Correlation of H. pylori and Eosinophilic Esophagitis. Gastroenterology. 146(5):S-677.

51. Okada H, Kuhn C, Feillet H, Bach JF. The 'hygiene hypothesis' for autoimmune and allergic diseases: an update. Clin Exp Immunol. 2010; 160(1):1-9. [PubMed: 20415844]

52. Blaser MJ. Helicobacter pylori and esophageal disease: wake-up call? Gastroenterology. 2010; 139(6):1819-22. [PubMed: 21029801]

53. Delaney B, McColl K. Review article: Helicobacter pylori and gastro-oesophageal reflux disease. Alimentary pharmacology \& therapeutics. 2005; 22(Suppl 1):32-40. [PubMed: 16042657]

54. Squires KA, Cameron DJ, Oliver M, da Fonseca Junqueira JC. Herpes simplex and eosinophilic oesophagitis: the chicken or the egg? J Pediatr Gastroenterol Nutr. 2009; 49(2):246-50. [PubMed: 19561550]

55. Zaja Franulovic O, Lesar T, Busic N, Tesovic G. Herpes simplex primo-infection in an immunocompetent host with eosinophilic esophagitis. Pediatrics international : official journal of the Japan Pediatric Society. 2013; 55(3):e38-41. [PubMed: 23782375] 
56. Lindberg GM, Van Eldik R, Saboorian MH. A case of herpes esophagitis after fluticasone propionate for eosinophilic esophagitis. Nat Clin Pract Gastroenterol Hepatol. 2008; 5(9):527-30. [PubMed: 18758471]

57. Monsanto P, Almeida N, Cipriano MA, Gouveia H, Sofia C. Concomitant herpetic and eosinophilic esophagitis-a causality dilemma. Acta gastro-enterologica Belgica. 2012; 75(3):3613. [PubMed: 23082710]

58. Machicado J, Younes M, Amaning J, Gomez-Esquivel R, Wolf D. Concomitant Herpetic and Eosinophilic Esophagitis in a Young Immunocompetent Adult: Unlikely Just a Rare Coincidence? American Journal of Gastroenterology. 2013; 108:S20-S.

59. Srivastava M MD. Pneumoniae Is a Potential Trigger for Eosinophilic Esophagitis. J Allergy Clin Immun. 131(2):AB177.

60. Burk CMBR, Lund PK, Dellon ES. High rate of galactose-alpha-1,3-galactose sensitization in both eosinophilic esophagitis and patients undergoing upper endoscopy. Diseases of the Esophagus. 2015

61. Bonis PA. Putting the puzzle together: epidemiological and clinical clues in the etiology of eosinophilic esophagitis. Immunol Allergy Clin North Am. 2009; 29(1):41-52. [PubMed: 19141340]

62. Codispoti CD, Levin L, LeMasters GK, Ryan P, Reponen T, Villareal M, et al. Breast-feeding, aeroallergen sensitization, and environmental exposures during infancy are determinants of childhood allergic rhinitis. J Allergy Clin Immunol. 2010; 125(5):1054-60 e1. [PubMed: 20392478]

63. Verhasselt V. Neonatal tolerance under breastfeeding influence: the presence of allergen and transforming growth factor-beta in breast milk protects the progeny from allergic asthma. $\mathbf{J}$ Pediatr. 2010; 156(2 Suppl):S16-20. [PubMed: 20105659]

64. Gronlund MM, Lehtonen OP, Eerola E, Kero P. Fecal microflora in healthy infants born by different methods of delivery: permanent changes in intestinal flora after cesarean delivery. $\mathbf{J}$ Pediatr Gastroenterol Nutr. 1999; 28(1):19-25. [PubMed: 9890463]

65. Dellon ES. Epidemiology of Eosinophilic Esophagitis. Gastroenterology clinics of North America. 2014; 43(2):201-+. [PubMed: 24813510]

66. Jensen ET, Kappelman MD, Kim H, Ringel-Kulka T, Dellon ES. Early life exposures as risk factors for pediatric eosinophilic esophagitis. J Pediatr Gastroenterol Nutr. 2013; 57(1):67-71. [PubMed: 23518485]

67. Radano MC, Yuan Q, Katz A, Fleming JT, Kubala S, Shreffler W, et al. Cesarean section and antibiotic use found to be associated with eosinophilic esophagitis. The journal of allergy and clinical immunology In practice. 2014; 2(4):475-7 e1. [PubMed: 25017541]

68. Boath EH, Blenkinsopp A. The rise and rise of proton pump inhibitor drugs: patients' perspectives. Soc Sci Med. 1997; 45(10):1571-9. [PubMed: 9351147]

69. Landres RT, Kuster GG, Strum WB. Eosinophilic esophagitis in a patient with vigorous achalasia. Gastroenterology. 1978; 74(6):1298-301. [PubMed: 648822]

70. Barron JJ, Tan H, Spalding J, Bakst AW, Singer J. Proton pump inhibitor utilization patterns in infants. J Pediatr Gastroenterol Nutr. 2007; 45(4):421-7. [PubMed: 18030207]

71. Hassall E. Over-prescription of acid-suppressing medications in infants: how it came about, why it's wrong, and what to do about it. J Pediatr. 2012; 160(2):193-8. [PubMed: 22018908]

72. Merwat SN, Spechler SJ. Might the use of acid-suppressive medications predispose to the development of eosinophilic esophagitis? Am J Gastroenterol. 2009; 104(8):1897-902. [PubMed: 19661930]

73. Mullin JM, Valenzano MC, Whitby M, Lurie D, Schmidt JD, Jain V, et al. Esomeprazole induces upper gastrointestinal tract transmucosal permeability increase. Alimentary pharmacology \& therapeutics. 2008; 28(11-12):1317-25. [PubMed: 18684245]

74. Hopkins AM, McDonnell C, Breslin NP, O'Morain CA, Baird AW. Omeprazole increases permeability across isolated rat gastric mucosa pre-treated with an acid secretagogue. J Pharm Pharmacol. 2002; 54(3):341-7. [PubMed: 11902800] 
75. Perrier C, Thierry AC, Mercenier A, Corthesy B. Allergen-specific antibody and cytokine responses, mast cell reactivity and intestinal permeability upon oral challenge of sensitized and tolerized mice. Clinical and Experimental Allergy. 2010; 40(1):153-62. [PubMed: 19689461]

76. Untersmayr E, Scholl I, Swoboda I, Beil WJ, Forster-Waldl E, Walter F, et al. Antacid medication inhibits digestion of dietary proteins and causes food allergy: A fish allergy model in Balb/c mice. J Allergy Clin Immun. 2003; 112(3):616-23. [PubMed: 13679824]

77. Untersmayr E, Bakos N, Scholl I, Kundi M, Roth-Walter F, Szalai K, et al. Anti-ulcer drugs promote IgE formation toward dietary antigens in adult patients. Faseb Journal. 2005; 19(1):656+. [PubMed: 15671152]

78. Ramirez E, Cabanas R, Laserna LS, Fiandor A, Tong H, Prior N, et al. Proton pump inhibitors are associated with hypersensitivity reactions to drugs in hospitalized patients: a nested case-control in a retrospective cohort study. Clinical and Experimental Allergy. 2013; 43(3):344-52. [PubMed: 23414543]

79. Mulder B, Schuiling-Veninga CCM, Bos HJ, De Vries TW, Jick SS, Hak E. Prenatal exposure to acid-suppressive drugs and the risk of allergic diseases in the offspring: a cohort study. Clinical and Experimental Allergy. 2014; 44(2):261-9. [PubMed: 24164287]

80. Hak E, Mulder B, Schuiling-Veninga CCM, de Vries TW, Jick SS. Use of Acid-Suppressive Drugs in Pregnancy and the Risk of Childhood Asthma: Bidirectional Crossover Study using the General Practice Research Database. Drug Safety. 2013; 36(11):1097-104. [PubMed: 24018582]

81. Andersen AB, Erichsen R, Fau-Farkas DK, Farkas Dk, Fau-Mehnert F, Mehnert F, Fau-Ehrenstein V, Ehrenstein V, Fau-Sorensen HT, Sorensen HT. Prenatal exposure to acid-suppressive drugs and the risk of childhood asthma: a population-based Danish cohort study. (1365-2036 (Electronic)).

82. Szepfalusi Z, Pichler J, Elsasser S, van Duren K, Ebner C, Bernaschek G, et al. Transplacental priming of the human immune system with environmental allergens can occur early in gestation. $\mathbf{J}$ Allergy Clin Immun. 2000; 106(3):530-6. [PubMed: 10984374]

83. Szepfalusi Z, Loibichler C, Pichler J, Reisenberger K, Ebner C, Urbanek R. Direct evidence for transplacental allergen transfer. Pediatr Res. 2000; 48(3):404-7. [PubMed: 10960510]

84. Scholl I, Ackermann U, Ozdemir C, Blumer N, Dicke T, Sel S, et al. Anti-ulcer treatment during pregnancy induces food allergy in mouse mothers and a Th2-bias in their offspring. Faseb Journal. 2007; 21(4):1264-70. [PubMed: 17227952]

85. Moawad FJ, Maydonovitch CL, Lake JM, Veerappan GR. PPIs May Not Predispose to Eosinophilic Esophagitis. American Journal of Gastroenterology. 2010; 105(2):468-9. [PubMed: 20139878]

86. Orel R, Turk H. Re: Might the Use of Acid-Suppressive Medications Predispose to the Development of Eosinophilic Esophagitis? American Journal of Gastroenterology. 2010; 105(2): 468-. [PubMed: 20139879]

87. Calabrese C, Bortolotti M, Fabbri A, Areni A, Cenacchi G, Scialpi C, et al. Reversibility of GERD ultrastructural alterations and relief of symptoms after omeprazole treatment. Am J Gastroenterol. 2005; 100(3):537-42. [PubMed: 15743348] 


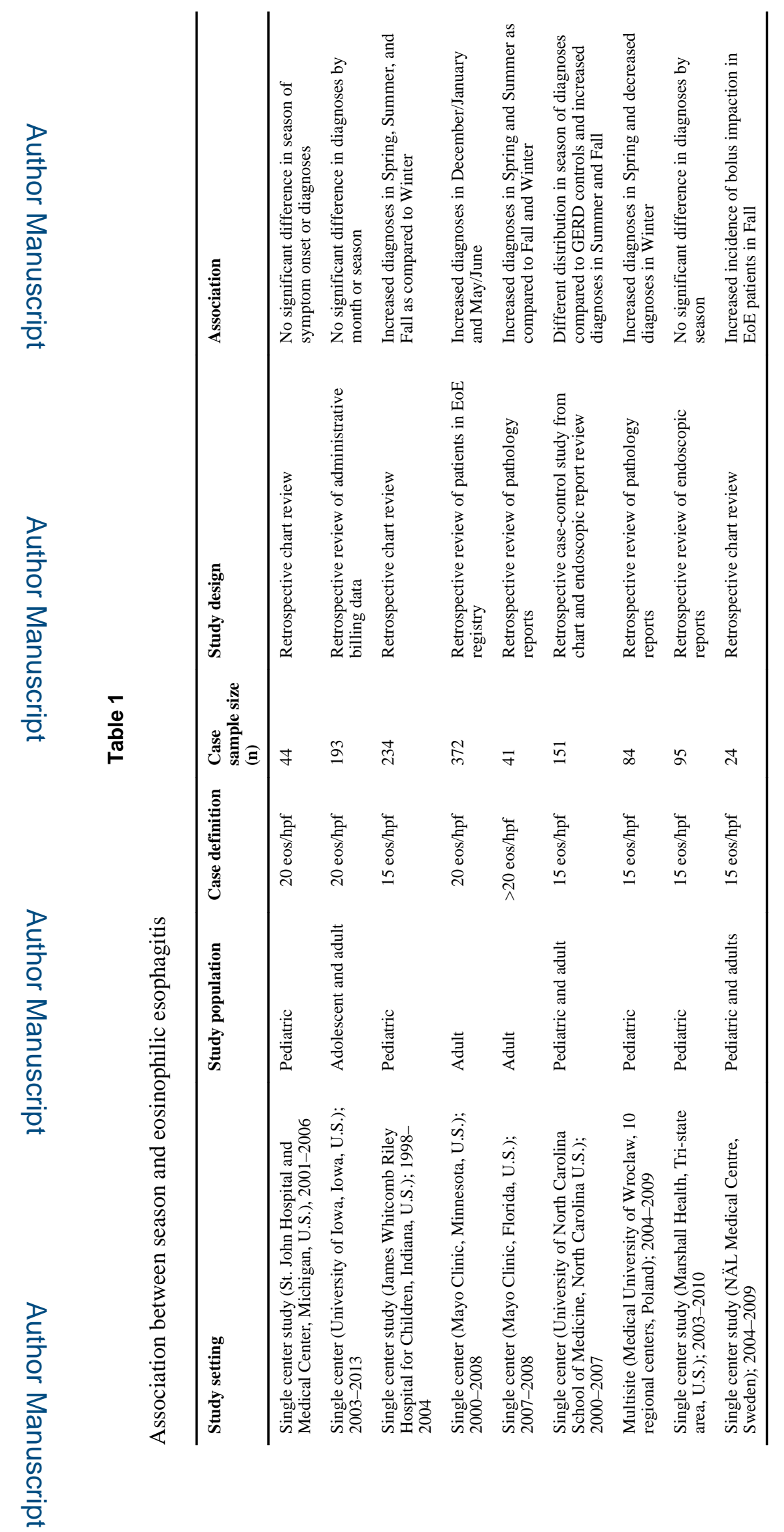

Best Pract Res Clin Gastroenterol. Author manuscript; available in PMC 2016 October 01. 


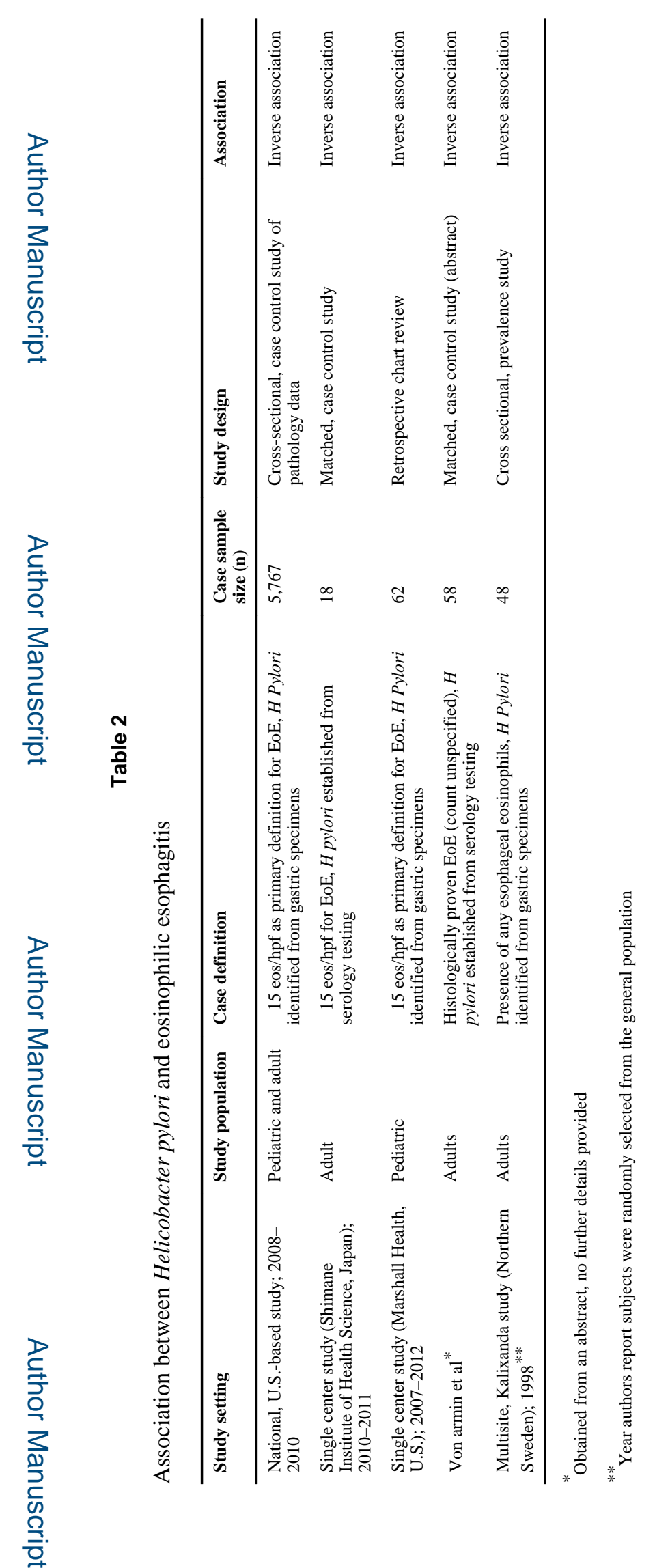

Best Pract Res Clin Gastroenterol. Author manuscript; available in PMC 2016 October 01. 